\title{
Dialectical model of character and Franklin's method
}

\section{Cätälin Mamali}

Abstract: The study analysis three personalities who generated selfrecords for a long period of time on their personality development and especially on character questions. The autobiographies** of Franklin, Gandhi and Thoreau's Walden experiment are studied as paradigmatic modes of enhancing intentionally one's own autonomy as a necessary condition to increase the personal ability to cope with major social conflicts for the sake of common good. The educational value of Franklin's methods for character training is based on practical exercises carried with students.

Keywords: Autonomy consistency/inconsistency, self-control, character-construction

\section{Autonomy across three cases - Franklin, Thoreall, Gandhi - and across levels of social complexity}

Based on the major autobiographical documents of the three personalities and on other documents and letters the study explored the similarities and dissimilarities of these tree personalities across three major levels of social complexity: intra-individual, interpersonal and societal. At each level have been used a number of indicators that are presented in Table 6.

It is expected that in major life-instances the activities of Franklin, Thoreau, Gandhi satisfied the criteria listed

\footnotetext{
* independent scholar (Northeast lowa Community College, U.S.A).

Catalin.Mamali@loras.edu
} 
Table 1. However, in addition were used the following criteria: levels of social complexity (individual, interpersonal, and macro-social), principles, character. All three tried to maintain a healthy body and practiced exercises of different types. Franklin's observations on physical exercises are doubled by objective measures (time, length, weight) and by innovative criteria such as the "quantum ...the degree of warmth it [physical exercise] produces in the body"1.

In this section the task will be used a limited number of criteria for three levels of social complexity: personal level, interpersonal level/small group level, macro-social level (social categories, nation, cultural). The specific indicators are: types of motives, techniques of self-control under external pressure, and character (individual level); motives and principles for interpersonal relationships, coping with enemies or persons with opposite attitudes or choices in relation to major social trends and moral values. For the sake of brevity I will present in more details Thoreau's case and will indicate similarities and especially the differences between him Franklin and Gandhi. Because autonomy is approached within the life context of each personality and because each of them faced huge pressures it is useful to recall Grolnick's conception on "autonomy supportive events" 2 . She defines as autonomy supportive those events that "lead a person to experience his or her behavior as initiated from within" while controlling events lead the person to experience one's own behavior as "being initiated

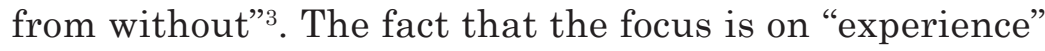
and not on the event as such, which is useful for exploring autonomy in the cases of Franklin, Thoreau and Gandhi who achieved autonomy despite aversive external conditions. The expression and development of autonomy within a controlling context seems to start with individual decision and will to non-participate, to separate oneself form

1 B. Franklin, The completed autobiography by Benjamin Franklin, compiled and edited by Mark Skousen, Washington 2006, p. 73.

1 W. S. Grolnick, The psychology of parental control. How wellmeant parenting backfires. Mahwah, New Jersey 2003.

3 Ibidem, p. 15. 
the controlling forces. An authentic participation is possible if and only if the individual has the right, the ability and the will of non-participation. This is in fact a principle established by Thoreau that is at the heart of civil disobedience.

All of them respected strict behavioral rules, relational norms. They displayed different orientations toward hedonism, as it is defined in Waterman's model ${ }^{4}$. Franklin was the most inclined to accept hedonism and Gandhi the least inclined, and all of them had a strong eudaimonic orientation striving to achieve goals that had a high moral value.

Table 1. Areas and types autonomy across life-span based on autobiographical documents. An overview of autonomy at the main levels of social complexity in the case of Franklin, Thoreau and Gandhi

\begin{tabular}{|c|c|c|c|}
\hline $\begin{array}{c}\text { Areas } \\
\text { of autonomy } \\
\text { and autono- } \\
\text { mous } \\
\text { self-control } \\
\text { at different } \\
\text { levels of social } \\
\text { complexity }\end{array}$ & $\begin{array}{c}\text { Benjamin } \\
\text { Franklin } \\
(1706-1790)\end{array}$ & $\begin{array}{c}\text { Henry D. Tho- } \\
\text { reau }(1817- \\
1862)\end{array}$ & $\begin{array}{c}\text { Mohandas } \\
\text { Karamchand } \\
\text { (Mahatma) } \\
\text { Gandhi } \\
(1869-1948)\end{array}$ \\
\hline $\begin{array}{l}\text { I. Individual } \\
\text { level } \\
\text { 1. Basic needs: } \\
\text { - Diet }\end{array}$ & $\begin{array}{l}\text { Practiced vege- } \\
\text { tarianism, gave } \\
\text { up, practiced } \\
\text { frugality }\end{array}$ & $\begin{array}{l}\text { Vegetarian- } \\
\text { ism preferred } \\
\text { and practiced } \\
\text { in a relaxed } \\
\text { mode }\end{array}$ & $\begin{array}{l}\text { Vegetari- } \\
\text { anism prac- } \\
\text { ticed in a strict } \\
\text { mode, giving up } \\
\text { even milk }\end{array}$ \\
\hline $\begin{array}{l}\text { - Body needs: } \\
\text { Physical exer- } \\
\text { cises }\end{array}$ & $\begin{array}{l}\text { Regular exer- } \\
\text { cises (swim- } \\
\text { ming; running } \\
\text { while car- } \\
\text { ing two loads } \\
\text { of lead); "degree } \\
\text { of warmth" }\end{array}$ & $\begin{array}{l}\text { Long walks, } \\
\text { physical } \\
\text { activities } \\
\text { around the } \\
\text { house (clearing }\end{array}$ & $\begin{array}{l}\text { Long walks, } \\
\text { physical work } \\
\text { (such as spin- } \\
\text { ning the wheal) } \\
\text { and physical } \\
\text { postures (asa- } \\
\text { na) }\end{array}$ \\
\hline $\begin{array}{l}\text { - Sleep/awake } \\
\text { cycle }\end{array}$ & $\begin{array}{l}\text { Regular, early } \\
\text { morning }\end{array}$ & $\begin{array}{l}\text { Regular, early } \\
\text { morning ( } 6 \text { am } \\
\text { is a self-record- } \\
\text { ed time) }\end{array}$ & $\begin{array}{l}\text { Regular, very } \\
\text { early morning }\end{array}$ \\
\hline
\end{tabular}

4 A.S. Waterman, "When effort is enjoyed: Two studies of intrinsic motivation for personally salient activities", Motivation and Emotion, 2005: 29, 3, pp. 165-188. 


\begin{tabular}{|c|c|c|c|}
\hline $\begin{array}{l}\text { - Care for one's } \\
\text { own health }\end{array}$ & $\begin{array}{l}\text { Used air bath- } \\
\text { ing, and } \\
\text { personal proce- } \\
\text { dures against } \\
\text { cold }\end{array}$ & $\begin{array}{l}\text { Considered } \\
\text { care for one's } \\
\text { body as a sign } \\
\text { of prudence }\end{array}$ & $\begin{array}{l}\text { Self-applied } \\
\text { traditional } \\
\text { medical reme- } \\
\text { dies }\end{array}$ \\
\hline $\begin{array}{l}\text { - Alcohol and } \\
\text { other addictive } \\
\text { substances }\end{array}$ & $\begin{array}{l}\text { No alcohol } \\
\text { use while col- } \\
\text { leagues used } \\
\text { to drink during } \\
\text { work }\end{array}$ & $\begin{array}{l}\text { No alcohol, no } \\
\text { stimulants }\end{array}$ & $\begin{array}{l}\text { No alcohol, no } \\
\text { smoking }\end{array}$ \\
\hline - Sexual drive & $\begin{array}{l}\text { Permissive and } \\
\text { controlled }\end{array}$ & $?$ & $\begin{array}{l}\text { Adopted celi- } \\
\text { bacy }\end{array}$ \\
\hline $\begin{array}{l}\text { 2. Emotional } \\
\text { control }\end{array}$ & $\begin{array}{l}\text { Control of neg- } \\
\text { ative emotions } \\
\text { (anger, disgust) } \\
\text { and expression } \\
\text { of positive feel- } \\
\text { ings, humor }\end{array}$ & $\begin{array}{l}\text { Control of neg- } \\
\text { ative emotions } \\
\text { (anger, disgust) } \\
\text { Politeness }\end{array}$ & $\begin{array}{l}\text { Control of neg- } \\
\text { ative emotions } \\
\text { (anger, disgust) } \\
\text { expression } \\
\text { of positive feel- } \\
\text { ings, smiling }\end{array}$ \\
\hline $\begin{array}{l}\text { 3.1. Motivation } \\
\text { - hedonism and } \\
\text { eudaimonia }\end{array}$ & $\begin{array}{l}\text { Intrinsic moti- } \\
\text { vation in self } \\
\text { rewarding } \\
\text { activities (play, } \\
\text { scientific inqui- } \\
\text { ry) and ability } \\
\text { to find intrin- } \\
\text { sic rewards } \\
\text { in social } \\
\text { duties; prefers } \\
\text { eudaimonia }\end{array}$ & $\begin{array}{l}\text { Intrinsic moti- } \\
\text { vation in con- } \\
\text { ducting his life, } \\
\text { observations \& } \\
\text { Walden exper- } \\
\text { iment, includ- } \\
\text { ing the chores } \\
\text { implied by his } \\
\text { mode of living, } \\
\text { moral duty \& } \\
\text { eudaimonia }\end{array}$ & $\begin{array}{l}\text { Ability to do } \\
\text { chores with joy, } \\
\text { to find intrin- } \\
\text { sic rewards } \\
\text { in hard tasks } \\
\text { (cleaning cham- } \\
\text { ber pots). } \\
\text { Rejects art for } \\
\text { the sake of art, } \\
\text { guided by mor- } \\
\text { al duty }\end{array}$ \\
\hline $\begin{array}{l}\text { 3.2. Universal } \\
\text { psychological } \\
\text { needs: } \\
\text { Autonomy } \\
\text { Competence } \\
\text { Relatedness }\end{array}$ & $\begin{array}{l}\text { - high autono- } \\
\text { my } \\
\text { - high compe- } \\
\text { tence } \\
\text { - high related- } \\
\text { ness }\end{array}$ & $\begin{array}{l}\text { - high autono- } \\
\text { my } \\
\text { - high compe- } \\
\text { tence } \\
\text { - high non- } \\
\text {-mediated } \\
\text { relatedness }\end{array}$ & $\begin{array}{l}\text { - high autono- } \\
\text { my } \\
\text { - high compe- } \\
\text { tence } \\
\text { - high related- } \\
\text { ness }\end{array}$ \\
\hline $\begin{array}{l}\text { 3.3. Motivatio- } \\
\text { nal intelligence }\end{array}$ & $\begin{array}{l}\text { - good read- } \\
\text { er of other's } \\
\text { motives }\end{array}$ & $\begin{array}{l}\text { - balance } \\
\text { of basic needs } \\
\text { and higher } \\
\text { needs }\end{array}$ & $\begin{array}{l}\text { - good read- } \\
\text { er of other's } \\
\text { motives }\end{array}$ \\
\hline $\begin{array}{l}\text { 4.Speech self- } \\
\text { control, } \\
\text { Silence }\end{array}$ & $\begin{array}{l}\text { Reduc- } \\
\text { ing unneces- } \\
\text { sary talk, use } \\
\text { of letters and } \\
\text { written self-ex- } \\
\text { pression }\end{array}$ & $\begin{array}{l}\text { Retreat (soli- } \\
\text { tude), } \\
\text { use of letters } \\
\text { and written } \\
\text { self-expression }\end{array}$ & $\begin{array}{l}\text { Silence strike, } \\
\text { letters and } \\
\text { written self-ex- } \\
\text { pression }\end{array}$ \\
\hline
\end{tabular}




\begin{tabular}{|c|c|c|c|}
\hline $\begin{array}{l}\text { 5. Cogni- } \\
\text { tive, rational } \\
\text { self-control: } \\
\text { - Personal } \\
\text { methods or pro- } \\
\text { cedures }\end{array}$ & $\begin{array}{l}\text { - Franklin's } \\
\text { matrix for } \\
\text { training virtues } \\
\text { - Moral algebra } \\
\text { - Self-examina- } \\
\text { tion procedurę }\end{array}$ & $\begin{array}{l}\text { - Introspection } \\
\text { guided by prin- } \\
\text { ciples } \\
\text { - Personal test } \\
\text { of basic needs' } \\
\text { threshold, } \\
\text { Walden experi- } \\
\text { ment, civil dis- } \\
\text { obedience }\end{array}$ & $\begin{array}{l}\text { - Meditation } \\
\text { - Experiments } \\
\text { with truth }\end{array}$ \\
\hline $\begin{array}{l}\text { - Focus on } \\
\text { facts, rejection } \\
\text { of stereotypes, } \\
\text { prejudices }\end{array}$ & $\begin{array}{l}\text { - Rejection } \\
\text { of speculation } \\
\text { (Mesmer's case) }\end{array}$ & $\begin{array}{l}\text { - Unobtrusive } \\
\text { observation, } \\
\text { friendly rela- } \\
\text { tions between } \\
\text { observer and } \\
\text { observed }\end{array}$ & $\begin{array}{l}\text { - Collecting } \\
\text { direct data } \\
\text { (Indian vil- } \\
\text { lages, etc.), } \\
\text { participative } \\
\text { observation }\end{array}$ \\
\hline $\begin{array}{l}\text { - Experimen- } \\
\text { tally oriented }\end{array}$ & $\begin{array}{l}\text { - Use of exper- } \\
\text { iments for test- } \\
\text { ing personal, } \\
\text { interperson- } \\
\text { al and physical } \\
\text { processes }\end{array}$ & $\begin{array}{l}\text { - Use of the } \\
\text { self-experi- } \\
\text { ment for test- } \\
\text { ing personal } \\
\text { limits and } \\
\text { social beliefs. }\end{array}$ & $\begin{array}{l}\text { - Systemat- } \\
\text { ic analysis } \\
\text { of one's own } \\
\text { experiences } \\
\text { and }\end{array}$ \\
\hline $\begin{array}{l}\text { - Executive } \\
\text { attention } \\
\text { and effortful } \\
\text { self-control } \\
\text { in conflicting } \\
\text { situations }\end{array}$ & $\begin{array}{l}\text { - Distin- } \\
\text { guish between } \\
\text { wrong choices } \\
\text { of friends and } \\
\text { correct solu- } \\
\text { tions of ene- } \\
\text { mies }\end{array}$ & $\begin{array}{l}\text { - Reject mis- } \\
\text { conceptions } \\
\text { of closed one }\end{array}$ & $\begin{array}{l}\text { Distinguish } \\
\text { between } \\
\text { wrong choices } \\
\text { of friends and } \\
\text { correct solu- } \\
\text { tions of ene- } \\
\text { mies }\end{array}$ \\
\hline $\begin{array}{l}\text { 6. Moral and } \\
\text { spiritual self- } \\
\text { control }\end{array}$ & $\begin{array}{l}\text { Regular eval- } \\
\text { uation of one's } \\
\text { deeds and } \\
\text { plans by the } \\
\text { help of mor- } \\
\text { al and religious } \\
\text { standards, use } \\
\text { of spiritual } \\
\text { models }\end{array}$ & $\begin{array}{l}\text { Regular eval- } \\
\text { uation of per- } \\
\text { sonal actions } \\
\text { and goals } \\
\text { by the help } \\
\text { of high mor- } \\
\text { al principles, } \\
\text { use of spiritu- } \\
\text { al models, "life } \\
\text { with principles" }\end{array}$ & $\begin{array}{l}\text { Strict appli- } \\
\text { cation of the } \\
\text { principle of axi- } \\
\text { ological conso- } \\
\text { nance between } \\
\text { means and } \\
\text { goals, too good } \\
\text { goals only by } \\
\text { good means }\end{array}$ \\
\hline $\begin{array}{l}\text { 7. Ability } \\
\text { to accept and } \\
\text { cope with per- } \\
\text { sonal sacrifices }\end{array}$ & Yes & Yes & Yes \\
\hline $\begin{array}{l}\text { 8. Cultivation } \\
\text { of character } \\
\text { goodness and } \\
\text { strengths (see } \\
\text { appendix 2) }\end{array}$ & $\begin{array}{l}\text { Yes, developed } \\
\text { a technique } \\
\text { to cultivate } \\
\text { character }\end{array}$ & $\begin{array}{l}\text { Yes, character } \\
\text { formation can } \\
\text { be cultivated } \\
\text { in the "stream } \\
\text { of the world" }\end{array}$ & $\begin{array}{l}\text { Yes, charac- } \\
\text { ter cultivation } \\
\text { considered at } \\
\text { least as import- } \\
\text { ant as Math, } \\
\text { grammar etc. }\end{array}$ \\
\hline
\end{tabular}




\begin{tabular}{|c|c|c|c|}
\hline $\begin{array}{l}\text { II. Interper- } \\
\text { sonal level } \\
\text { - Self-control } \\
\text { in relation with } \\
\text { opponents and } \\
\text { enemies }\end{array}$ & $\begin{array}{l}\text { - Control } \\
\text { of negative } \\
\text { interperson- } \\
\text { al feelings and } \\
\text { conversion into } \\
\text { positive ones } \\
\text { (Franklin's } \\
\text { method to ask } \\
\text { favors from } \\
\text { enemies) }\end{array}$ & $\begin{array}{l}\text { - Polite, } \\
\text { respect- } \\
\text { ful behavior } \\
\text { toward the tax } \\
\text { collector }\end{array}$ & $\begin{array}{l}\text { - Concern to be } \\
\text { fair toward ene- } \\
\text { mies, iden- } \\
\text { tifying the } \\
\text { areas in which } \\
\text { the enemies } \\
\text { are right and } \\
\text { acknowledg- } \\
\text { ing it }\end{array}$ \\
\hline $\begin{array}{l}\text {-Self control } \\
\text { in intimate } \\
\text { (including sex- } \\
\text { ual) relation- } \\
\text { ships }\end{array}$ & $\begin{array}{l}\text { - Expressed } \\
\text { and as goal, } \\
\text { engaged in many } \\
\text { intimate rela- } \\
\text { tionships but } \\
\text { without produc- } \\
\text { ing }\end{array}$ & $\begin{array}{l}\text { - Failure } \\
\text { to establish } \\
\text { intimate long } \\
\text { term intimate } \\
\text { relationships }\end{array}$ & $\begin{array}{l}\text { - Pre-arranged } \\
\text { marriage, } \\
\text { adaptation, } \\
\text { celibacy after } \\
\text { debating his } \\
\text { decision with } \\
\text { wife }\end{array}$ \\
\hline $\begin{array}{l}\text { - self-control } \\
\text { and mutual } \\
\text { respect }\end{array}$ & $\begin{array}{l}\text { Use of interper- } \\
\text { sonal (psycho- } \\
\text { social) tests } \\
\text { to solve con- } \\
\text { flicts } \\
\text { - Ability } \\
\text { to cope with } \\
\text { a wide range } \\
\text { of relationship }\end{array}$ & $\begin{array}{l}\text { - Friendly, } \\
\text { polite relation- } \\
\text { ships }\end{array}$ & $\begin{array}{l}\text { - Ability } \\
\text { to cope with } \\
\text { a wide range } \\
\text { of relationships }\end{array}$ \\
\hline $\begin{array}{l}\text { - Resistance } \\
\text { on rational and } \\
\text { factual grounds } \\
\text { to opinions and } \\
\text { group pres- } \\
\text { sures }\end{array}$ & $\begin{array}{l}\text { Ability } \\
\text { to remain calm } \\
\text { and close to the } \\
\text { facts and his } \\
\text { beliefs regard- } \\
\text { less pressure } \\
\text { from others, } \\
\text { and groups }\end{array}$ & $\begin{array}{l}\text { Ability } \\
\text { to remain calm } \\
\text { and close to the } \\
\text { facts and his } \\
\text { beliefs regard- } \\
\text { less pressure } \\
\text { from others, } \\
\text { and groups }\end{array}$ & $\begin{array}{l}\text { Ability } \\
\text { to remain calm } \\
\text { and close to the } \\
\text { facts and his } \\
\text { beliefs regard- } \\
\text { less pressure } \\
\text { from others, } \\
\text { and groups }\end{array}$ \\
\hline $\begin{array}{l}\text { III. Societal } \\
\text { and cultural } \\
\text { level: } \\
\text { - Autono- } \\
\text { my in relation } \\
\text { to societal views } \\
\text { and person- } \\
\text { al action aimed } \\
\text { to increase soci- } \\
\text { etal autonomy } \\
\text { (groups, nation) }\end{array}$ & $\begin{array}{l}\text { Serving } \\
\text { through one's } \\
\text { own agen- } \\
\text { cy the auton- } \\
\text { omy of larger } \\
\text { social groups } \\
\text { (even the entire } \\
\text { nation): } \\
\text { - stamp-act } \\
\text { - America's } \\
\text { independence }\end{array}$ & $\begin{array}{l}\text { Serving } \\
\text { through one's } \\
\text { own agen- } \\
\text { cy the auton- } \\
\text { omy of larger } \\
\text { social groups } \\
\text { (even the entire } \\
\text { nation): } \\
\text { - relations } \\
\text { between indi- } \\
\text { viduals and } \\
\text { government } \\
\text { - anti-slavery } \\
\text { movement }\end{array}$ & $\begin{array}{l}\text { Serving } \\
\text { through one's } \\
\text { own agency } \\
\text { the autonomy } \\
\text { of larger social } \\
\text { groups: } \\
\text { - the rights } \\
\text { of Indians } \\
\text { in South Africa; } \\
\text { - the autono- } \\
\text { my of untouch- } \\
\text { ables } \\
\text { - India's inde- } \\
\text { pendence }\end{array}$ \\
\hline
\end{tabular}




\begin{tabular}{|l|l|l|l|}
\hline -Self-reliance & $\begin{array}{l}\text { Self-reliance } \\
\text { of the individu- } \\
\text { al and of Amer- } \\
\text { ica (Colonies) }\end{array}$ & $\begin{array}{l}\text { Self-reliance } \\
\text { of the individ- } \\
\text { ual. of com- } \\
\text { munities, and } \\
\text { learning com- } \\
\text { munities }\end{array}$ & $\begin{array}{l}\text { Self-reliance } \\
\text { of the individu- } \\
\text { al, of villages, } \\
\text { of India }\end{array}$ \\
\hline
\end{tabular}

It seems that Franklin and Gandhi had a high ability to achieve self-control in strong social conflicts due to their ability to remain focused and especially to their ability to perceive value, real merits and valid critical comments in the actions generated by their adversaries. This was especially the case of Gandhi who trained himself to observe and recognize publicly the merits of his enemies. These abilities seem to be associated with control over negative thoughts and feelings and with the ability of reading in the enemies' behaviors positive side/signals ${ }^{5}$.

Franklin, Thoreau and Gandhi had a strong experimental and experiential orientation and a strong tendency to check information and opinions. This tendency was used for solving social problems, tensions and strong conflicts. It could be said that the behaviors of Franklin, Thoreau and Gandhi could be characterized by what Jonas and Brandstatter defined as "Zivilcourage" (moral courage) expressed in relationship of a wide range of civil rights ${ }^{6}$.

How Franklin practiced self-direction and self-control for serving high moral goals within an extremely stressful situation? Historical records that can help to answer have been produced and preserved due to the features of democratic cultures.

5 W. von Hippel, K. Gonsalkorale, "That is bloody revolting. Inhibitory control of thoughts better left unsaid", Psychological Science", 2005: 17, 7, pp. 497-500.

6 K. J. Jonas, V. Brandstatter, „Zivilcourage - Defintionen, Befunde, Massnahemn [Moral courage - definition, findings and intervention]“, Zeitschrift Fur Sozialpsychologie, 2004: 35, pp. 185-200. 


\section{Real life episodes that ask for high levels of autonomouls self-regulation: Franklin's interrogation regarding the Repeal of stamp act in the British Parliament}

A strong empirical question emerges: are all these methods and practices that ait to develop character, autonomous self-control and self-reliance paying off in real-life-situations? Franklin faced many difficult situations in his life as it is his efforts to repeal the STAMP-ACT. Description of the material: The material used here is provided by "The EXAMINATION of Doctor Benjamin Franklin by the AUGUST ASSEMBLY, relating to the Repeal of the STAMP-ACT, \&c". The actions against the Stamp-Act are grounded in the principle that people of one land cannot be taxed and their trade restrained by legislature in which they are not represented and have no saying about it. This is a problem of a greater autonomous self-control of the colonies, which at the same time display higher levels of self-reliance. Franklin dedicated himself to this specific goal of the colonies.

Franklin took great care to make copies of the records, to number the questions and to indicate who asked the questions, especially if the person was a friend or an enemy of us (the American colonies). There were 174 questions asked to Franklin, but the meaning of his answer remains intact.

Assumptions: it is assumed that the mode of answering questions under a close examination on a vital personal, group or societal issue that has also high moral ramifications, could be used to identify the degree of the autonomous self-control, including one' s moral autonomy, of the questioned person.

The major indicators of autonomous self-control are the following:

1) Consistency of the provided answers with the main goal of Franklin's action: repeal of the Stamp Act (greater autonomy for the people represented by him).

2) Keeping his focus on the major goal in the face of hypothetical and suggestive questions that were intentionally designed to trigger answers that favored the STAMP-ACT.

1 B. Franklin, Writings, Vol. 13, 1757-1775, (February 13 1766), London 1987, p. 129-159. 
3) Answers focused on the epistemic merit of the questions regardless the social origin of the questions (expressed by enemies or by friends),

4) Pro-active orientation aimed to point out the misrepresentations of the British representatives about the people and the situation in the colonies.

5) Use of counter-questions addressed to the examiners. From, previous studies it suggested that the tendency to generate questions and counter-questions are a sign that the user feels safe and consider that the roles of the questioned and questioner are reversible on an equal basis ${ }^{8}$.

6) Refusal to answer to the same questions or to questions considered improper and to repeated questions.

All of these indicators are considered valid for autonomous self-control if and only if the person succeeds to maintain its calm in the respective instance. As a general observation it has to be mentioned that under this highly stressful Franklin displayed a perfect self-control of his emotions and on his cognitive abilities. He remained focused on the task as such. Also it has to be mentioned that Franklin was never interrupted and even the trickiest (highly suggestive) questions were stated in a polite mode. The interrogatorily mode of the examination is evident from the prevalence of yes/no questions and of hypothetical and suggestive questions.

Examples of a few types of questions and answers:

Yes/No questions: Q "Are not all the people very able to pay those taxes?" A "No. The frontier counties, all along the continent, having being frequently ravaged by the enemy, and greatly impoverished are able to pay very little tax..."9

Q "Is there a power on earth that can force them [the assemblies of America] to erase them [their resolutions]?"A "No power, how great soever, can force men to change their opinions"10.

${ }^{8}$ C. Mamali, Oracle-Sphinx complex: Oedipus's quest for truth and love, Manuscript: University of Iowa, Project on Rhetoric of Inquiry, Iowa City - Dubuque 1992/2000.

' B. Franklin, Writings, Vol. 13, 1757-1775, (February 13 1766), London 1987, p. 130.

${ }^{10}$ Ibid., p. 170. 
What questions (seven word-questions): Q "What are the present taxes in Pennsylvania, laid by the laws of the colony?" A "There are taxes on all estates real and personal, a poll tax, a tax on all offices, professions, trades and businesses, according to their profits... and a duty of Ten Pounds per head on all Negroes imported..." 11

Q "What used to be the pride of the Americans?"A "To indulge in the fashion and manufactures of Great-Britain." Q "What is now their pride?"- A "To wear their old cloths over again, till they can make new ones"12.

Suggestive question with an implied answer: Q "Can anything less than a military force carry the stamp-act into execution?" A "I do not see how a military force can be applied to that purpose." Q "Why maybe not?" A "Suppose a military force sent into America, they will find nobody in arms; what are they then to do? [counter-question] They cannot force a man to take stamps who chooses to do without them. They will not find a rebellion; they may indeed make one" 13 . Q "Is it not necessary to send troops to America, to defend the Americans against the Indians?" A [counter-question include] "No, by no means; it never was necessary. They defended themselves when they were but a handful, and the Indians much more numerous... without any troops sent to their assistance from this country. And can it be thought necessary now to send troops for their defense from those diminished Indian tribes, when the Colonies are become so populous, and so strong?"14.

Hypothetical question without answer: Q "if the stampact should be repealed, and an act should pass, ordering the assembly of the colonies to indemnify the sufferers by the riots, would they obey it?" A "This is a question I cannot answer." (Q no. 132) ${ }^{15}$

The explicit relations between human needs and self-reliance: Q "Is it their interest not to take them [Americans interest to buy British goods]?" A "The goods they take from Britain are either necessaries, mere conveniences,

\footnotetext{
"Ibid., p. 130.

Il Ibid., p. 159.

B Ibid., p. 142.

14 Ibid., p. 152.

is Ibid., p. 153
} 
or superfluities. The first, as cloth, \&c with little industry they can make it at home; the second they can do without, till they are able to provide them among themselves; and the last, which are much the greatest part, they will strike off immediately. They are mere articles of fashion, purchased and consumed, because the fashion in the respected country, but will be now detested and rejected..."16

Findings:

Types of questions

Answers

No $=178$

Autonomy Consistent AC

Autonomy Inconsistent (I)

1. Yes/no questions

23.5

$\mathrm{AC}$

2. The seven word-questions

29.6

$\mathrm{AC}$

(what, who, which, where, when, why, how)

3. Do you know?

8.4

$\mathrm{AC}$

4. Do you think?

3.3

$\mathrm{AC}$

5. Clarification

1.1

$\mathrm{AC}$

6. Opinion

2.7

$\mathrm{AC}$

7. Can (it/we)?

4.5

$\mathrm{AC}$

8. Means

1.6

$\mathrm{AC}$

9. Hypothetical \& suggestive

25.3

$\mathrm{AC}$

All Franklin's answers were consistent with the autonomy principle at societal level and personal level.

Franklin, Thoreau and Gandhi worked for the achievement of self-reliance and moral autonomy not just at the individual level but also at societal level. Their individual moral autonomy is intertwined with their work for the autonomy of large social groups. However, there is a difference between Franklin on one side and Thoreau and Gandhi on the other side regarding: while Thoreau and Gandhi did not circumscribed their work for societal self-reliance to their group of origin and made programmatic efforts to help other groups such as American Indians, Black, Muslim, Untouchable people while Franklin limited his efforts to the America's colonists, mainly people of Western European extraction

${ }^{16}$ B. Franklin, January 1 through December 31, 1766, Yale University Press. New Haven 1969, p. 143. 
during his time. Franklin was an official representative of America in relation with Great Britain and his support of the collective self-reliance was focused on a specific objective. Franklin was ahead of his time but the major goal and mentality of the society represented by him restricted his pro-autonomy actions to the society he identified with. Within Franklin's mode of being this was just a step toward a much wider self-reliance and moral autonomy at societal level. He was convinced that in matters of principles the compromise is not a solution: "no middle ground could be well maintained: that Parliament had a power to make all laws for us, or that it had a power to make no laws for us" ${ }^{17}$. Also the fact that Franklin was not considering in his answers the self-reliance of African-American and Indians is a result of his pragmatic and step-by-step approach of self-reliance. As a matter of fact Franklin "while supporting a petition to the Congress against the slave trade, he wrote one of his most appealing hoaxes. In a letter to the Federal Gazette he offered a letter purportedly written a hundred years earlier by a fictitious Muslim statesman" against slavery ${ }^{18}$. His strategy implies the assumption that only self-reliant actors that have also moral autonomy could help others to reach self-reliance. It seems that Gandhi did not use the same strategy at the societal level, and at the individual level he considered that the self-reliant could be just an example for others and does not the right to force them to follow his way.

During the entire examination Franklin's autonomous self-control was impeccable at least in relation with the following three areas: a) cognitive focus (in all answers provided); b) emotional control (in all answers provided); c) explicit assertion of the autonomy potential of the people represented by him. The mode in which Franklin prepared for this examination, the mode in which he behaved during the examination, and the mode in which he approached the

" B. Franklin, The completed autobiography by Benjamin Franklin, compiled and edited by Mark Skousen, DC: Regnery Publishing Inc., Washington 2006, p. 65.

18 E. Morgan, Benjamin Franklin, Yale University, New Haven 2002, pp. 38-39. 
outcome of this examination (including its records) suggest that he was mainly intrinsically motivated. Long after the examination was over his interest in the issue remained high. However, besides it there are a few other elements that could be considered as factors that increased his autonomous self-control. For instance, the habit of systematic self-examination and the procedure used to cultivate one's own character, as Franklin designed these, are assumed to be causal factors of an increased autonomous self-control. These techniques designed by Franklin as his social experiments put in to the service of good goals are strong signs of his "moral imagination" as Tuan defined this concept ${ }^{19}$. These techniques are discussed in Appendix 1.

Franklin's case, as well as the experiences lived by Thoreau and Gandhi, do reveal some advantages and limits of the dialectical model of character. First of all Franklin's experiences reveal that even in the paradigmatic cases of good and strong character that had a major role in achieving societal goals that served the wellbeing of the entire community not all the components of the model must take a positive direction all the time. For instance, transparency that is an essential component for understanding the sense of one's own integrity has, many times during Franklin's life, a zigzagging trajectory because Franklin used cover-up and even deceiving strategies. He did it by signing with a pseudo-name certain articles sent to the newspaper directed by his own brother and turned himself into a direct witness of the reactions of the editors to the content of his own article without giving to the editors the chance even to imagine that he might be the author whose work is judged by them. He designed experimental situations to assess objectively the judgment of his own friends about the poetic talent of a colleague by resorting to epistemically grounded lies, as in many modern psycho-social experiments on stereotype and prejudice. He proved many times an efficient social imagination in order to reveal a truth that was obscured by denial. Franklin even impersonated, in his writing, a Muslim in order to plead publicly efficiently against slavery.

19 Y.F. Tuan, Morality and imagination. Paradoxes of progress, University of Wisconsin Press, Madison 1989. 
He covered his intentions and actions to unmask a British collaborator who worked against the American interests. However, in all these cases, his opacity, manipulative techniques and even deceptive strategies have been strongly and ultimately subordinated to serve truth, social justice and the vital interests of his country. The model helps to identify such deviations from integrity (mainly transparency) by taking into account the role of self-selected moral principles. But, the exact connection between these high self-selected moral principles still remains an question to be solved.

\section{Some findings gathered by the application of Franklin's matrix, conclusions and proposals}

I applied Franklin's method to over 700 volunteers. From this convenience sample 422 have been nontraditional students (71\% females, age range 18 to 56) Just two observations that need to be explored in a systematic mode by future research: a) 92 participants did complete from the first request the exercise during the time limit ( 2 weeks). From this $21.8 \%$ of the entire sample almost half (39) did add personal traits to the provided matrix. These participants have been also students that did provide always the class work on time, no later work; b) 116 participants did postpone, at least three times, the completion of Franklin's matrix. Out of these 27\% participants of the entire sample 73 did provide at least on time late work for mandatory tasks. The category (62.9\%) of participants who did not complete Franklin's matrix and at the same time had had late mandatory class work represent $17.3 \%$ from the entire convenience sample $(\mathrm{N}=422)$. However, if we contrast the category of those participants who did complete on time Franklin's matrix $(\mathrm{N}=92)$ with those participants who have been late at least one time $(\mathrm{N}=116)$ it is evident that the attitude toward Franklin's method informs us about other character dimensions such as order, resilience, respect for the time rule. Of course these findings have a preliminary nature that must be checked by experimental studies.

At the same time the model as well as these orienting findings invite the assumption that Franklin's method for constructing ones' own character has not only an informative 
value but it can have a positive transformative value. In order to verify this hypothesis a longitudinal study combined with and experimental design is needed.

The model of the "Dark triad" ${ }^{20}$ which has been developed into the more comprehensive model of "Dark tetrad" including Narcissism, Machiavellianism, psychopathy and Sadism ${ }^{21}$ establishes a new area of research that has been approached before only partially (Christie and Geis). It strongly suggests that it is necessary to explore the dangerous sides of personality that are many times systematically exercised by many people; this approach is theoretically fertile, morally significant and practically useful. Malevolent behavioral patterns and tendencies are not rare and, as you point out might have even, within specific social and cultural contexts and adaptive role in what you called "dark niches". At the present stage of the research both on character and on the dark tetrad of personality it is still extremely difficult to identify under what conditions the dark dimensions of personality and evil sides of character are the result of self-training and societal training and turning into self and socially-constructed character features. One of the most difficult questions is that character goodness/evilness and strengths are the result of long-term processes that should be studied longitudinally. From Franklin's case and method it emerges the idea that he was mainly focused on his character's failure, and kept a daily record in order to correct and improve it. Character is the complex outcome of a self-construction under specific life conditions but this construction takes a very long time and almost never ends. One's own character is built in relationships with others who might try to help the self or they might try to use their character strengths to deceive, manipulate and even degrade the self.

${ }^{20}$ D.L. Paulhus, K.M. Willimas, "The dark triad of personality: narcissism, machiavellianism and psychopathy", Journal of Research in Personality, 2002: 36, 6, pp. 556-563.

"A. Furnham, S.C. Richards, D. L. Paulhus, "The dark triad of personality: a 10 year review", Social and Personality Compass, 2013: 7, 3, pp. 199-216. H. Chabrol, T. Melioli, N. Van Leeuwen, R. Rodgers, R. Goutaudier, "The Dark Tetrad: Identifying personality profiles in high-school students", Personality and Individual Differences, 2015: 83, pp. 97-101. 


\section{Appendix 1 (Application)}

Franklin's method to learn about and to develop one's own character: An exercise in self-knowledge and self-improvement of character.

You are invited to participate to a practical exercise during a few weeks that aim to increase your knowledge of your own character and to improve it. The exercise is based on Benjamin Franklin's method practiced by him in order to increase the virtues and the strengths of his own personality, especially of his own character. Of course if you like this exercise you might continue. Also it might be possible that you might have used some of its elements prior to this exercise. Please read carefully all the information and instructions.

\section{Meaning of character}

Character is understood as a dynamic part (sub-system) of our personality that is closely related to all other sub-systems such as: cognitive abilities, motives, emotions, moral traits, habits and temperament. It is useful to remind that in a sample of over 400 introductory textbooks (some textbooks having 10 editions) for psychology (including developmental psychology and social psychology) published in the U.S.A. the concept of character is missing (it is not even in the subject index).

In contrast to temperament, which is mainly biologically rooted and present at birth, character is an acquired sub-system (a self-construction) that depends mainly on the individual's choices and actions, on the environment and on the relationships between individual and environment. Within the present exercise character is defined by a series of 4 (four) major components that are interrelated. These are:

1. Character Virtues: they help to distinguish between a good character (character goodness) and a bad character (character evilness). Among such virtues are: love, justice, charity, sincerity, humility and others.

2. Character Strengths (or character power) that help us to distinguish between a strong character 
and a weak character. Among such strengths are: endurance, will power, perseverance, resolution, self-control (thinking flow, speech, emotions, and behavior).

3. Character integrity it helps to distinguish between a unitary and a contradictory character. The major components of character integrity are: the inner thoughts and feelings, the speech and what is expressed, and the acts (the deeds). When there is agreement among all these components one could say that that a given character has positive or negative integrity. It includes; transparence versus opacity.

4. Orienting principle (major guiding principle). Some people might have dominant guiding principles: such as love of the other (neighbor and enemy); non-violence, any means are justified if we reach our goals, etc.

One has to have in mind that each and every individual has character. The question is: what type of character? Good or bad? Weak or strong? And of course any combinations such as a good and strong character, or a strong and evil character. Also one must ask oneself what type of character one would like to develop?

\section{Benjamin Franklin's method to learn and develop character.}

Based on his readings, including ancient Greek, including Pythagoras advices for a daily exercise of virtues, and on his own experience Franklin has identified the following Virtues and their Percepts:

1. TEMPERANCE: eat not to Dullness, Drink not to Elevation.

2. SILENCE: speak not but what may benefit others or yourself.

3. ORDER: Let all your Things have their Places...and Business have its Time.

4. RESOLUTION: Resolve to perform what you ought. Perform without fail what your resolve.

5. FRUGALITY: Waste nothing.

6. INDUSTRY: Lose no Time. - Cut off all unnecessary Actions.- 
7. SINCERITY: Use no hurtful Deceit. Think innocently and justly and if you speak; speak accordingly.

8. JUSTICE: Wrong none

9. MODERATION: Avoid Extremes.

10. CLEANLINESS: Tolerate no Uncleanness.

11. TRANQULITY: Be not disturbed by Trifles, or at Accidents.

12. CHASTITY: Rarely use Venery but for Health and Offspring.

13. HUMILITY (H): Imitate Jesus and Socrates. -

In order to know and train the virtues mentioned above Franklin established a set of tasks:

a) He selected that virtue/strength he considered to be the most important; b) He focused his "Attention" on that first choice; c) He worked on the selected Virtue for a time and was able to go during 13 weeks on all the Virtues/Strengths and repeat the cycle 4 times per year; d) At the end of each and every day he will mark with a black Spot every Fault in a matrix/table, recording his efforts and observations.

Form used as an example:

Days of the Week

\begin{tabular}{|l|c|c|c|c|c|c|c|c|}
\hline \multicolumn{1}{|c|}{ Virtues } & S & M & T & W & Th & F & Sa & $\begin{array}{c}\text { Total } \\
\text { Fail }\end{array}$ \\
\hline Temperance & $* *$ & $*$ & & $*$ & $*$ & $*$ & & \\
\hline Silence & $*$ & $* * *$ & $*$ & & $*$ & $*$ & $* *$ & \\
\hline Order & & $*$ & & & $* *$ & & & \\
\hline Resolution & & & & & & & & \\
\hline Frugality & & & & & & & & \\
\hline Industry & & & $*$ & & & & & \\
\hline Sincerity & & & & & & & & \\
\hline Justice & & & & & & $*$ & & \\
\hline Moderation & & & & & & $* *$ & & \\
\hline Cleanliness & & & & & & & & \\
\hline Tranquility & & $*$ & & & & & & \\
\hline Chastity & & & & & & $* *$ & & \\
\hline Humility & & $*$ & $*$ & $*$ & $*$ & & & \\
\hline
\end{tabular}


What is your task? You may use the same Virtues/ Strengths as those used by Franklin, add a few more, or you may work out a complete new list. In each of these situations you must:

1. Indicate the Virtue/Strength selected by you now to be the MAIN focus of your ATTENTION (mark it with letter $\mathbf{A}$ ).

2. Mark on it during the next 7 days, at the end of each day, how many times you failed to achieve it during the day by using the sign *.

3. You may use Franklin's list as it is, you may add a few components, but you indicate the MAIN Focus

4. You may create your own list (Personal list)

Franklin's list (include additions) and the traits added by you-

Days of the Week

\begin{tabular}{|l|l|l|l|l|l|l|l|l|}
\hline \multicolumn{1}{|c|}{ Virtues } & S & M & T & W & Th & F & Sa & $\begin{array}{c}\text { Total } \\
\text { Fail }\end{array}$ \\
\hline Franklin's list & & & & & & & & \\
\hline Temperance & & & & & & & & \\
\hline Silence & & & & & & & & \\
\hline Order & & & & & & & & \\
\hline Resolution & & & & & & & & \\
\hline Frugality & & & & & & & & \\
\hline Industry & & & & & & & & \\
\hline Sincerity, etc. & & & & & & & & \\
\hline $\begin{array}{l}\text { Traits added } \\
\text { by you }\end{array}$ & & & & & & & & \\
\hline & & & & & & & & \\
\hline
\end{tabular}

Bucharest June-July 2015 \& Dubuque August 2015, revised January 2017. 
Aung San Suu Kyi. (1991). Freedom from fear and other writings. Edited by M. Aris with contributions by Philip Kreager, Ann Pasternak Slater, Josef Silverstein \& Ma Than E. New York: Viking.

Bandura, A. (1998). Mechanisms of moral disengagement. W. Reich (Ed.), Origins of terrorism: Psychologies, ideologies, theologies, states of mind (pp. 161-101). New York: Cambridge University Press.

Bandura, A. (2000). Exercise of human agency through collective efficacy. Current Directions in Psychological Science, 9, 75-78.

Bandura, A. (2003). On the psychosocial impact and mechanisms of spiritual modeling. The International Journal for the Psychology of Religion, 13(3) 167-173.

Bandura, A. (2016). Moral disengagement. How people do harm and live with themselves. New York: Worth Publishers, Macmillan Learning.

Blasi, A. (2005). Moral character. A psychological approach. In D. K. Lapsley \& F. C. Power (Eds.), Character psychology and character education. Notre Dame Indiana: University of Notre Dame Press, (67-100).

Chabrol, H., Melioli,T., Van Leeuwen, N., Rodgers, R., \& Goutaudier, R. (2015). The Dark Tetrad: Identifying personality profiles in high-school students. Personality and Individual Differences, 83, 97-101.

Cloninger, C. R., Przybeck, T. R., Svrakic, \& Wetzel, R. D. (1994). The temperament and character inventory (TCI): a guide to its development and use. St. Louis, Missouri, Washington University, Center for Psychobiology of Personality.

Colby, A. \& Damon, W. (1992). Some do care. Contemporary lives of moral commitment. New York: The Free Press, McMillan.

Confucius and Lao Tzu (2005). The Analects of Confucius. Lao Tzu: Tao Te Ching. Translated with notes by Arthur Waley. New York: Barnes \& Nobles Constante, L. (1990). L'Evasion silancieuse. Paris: La Découverte.

Constante, L. (1996). Evadarea imposibilă. Bucureşti: Florile Dalbe.

Deci, E. L. (1975). Intrinsic motivation. New York: Plenum.

Deci, E. L. \& Ryan, R. M. (1985). Intrinsic motivation and self-determination in human behavior. New York: Plenum.

Deci, D. L. \& Ryan, R. M. (2000). The "what" and "why" of goal pursuits. Human needs and the self-determination of behavior. Psychological Inquiry, 4, 227-268.

Deci, E.L. \& Ryan, R. M. (2008a). Facilitating optimal motivation and psychological well-being across life's domains. Honorary President's Address, 2007, Canadian Psychology, 49, 14-23. 
Deci, E.L. \& Ryan, R. M (2008b). Self-determination theory: A macro theory of human motivation, development and health. Canadian Psychology, 49, 3, pp. 182-185.

Faschingbauer, T. R. \& Rubenzer, S. J. (2004). Personality, character, and leaderships in the White House. Washington D. C.: Brassey's Inc:

Franklin, B. (1969). January 1 through December 31, 1766. New Haven: Yale University Press.

Franklin, B. (2006). The completed autobiography by Benjamin Franklin. Compiled and edited by Mark Skousen. Washington, DC: Regnery Publishing Inc.

Franklin, B. (2003). A Benjamin Franklin reader. Edited annotated by Walter Isaacson.New York: Simon \& Schuster.

Franklin, B. (1987). Writings. Boston and London, 1722-1726; Philadelphia, 1726-1757; London, 1757-1775; Paris, 1776-1785; Philadelphia, 1785-1790; Poor Richard's Almanack, 1733-1758; The autobiography. New York: The Library of America.

Fromm, E. (1941). Escape from freedom. New York: Rinehat.

Fromm, E. \& Maccoby, M. (1970). Social character in a Mexican village: A sociopsychoanalytic study. Englewood Cliffs, NJ: Prentice: Hall.

Furnham, A., Richards, S.C. \& Paulhus,D. L.(2013). The dark triad of personality: a 10 year review. Social and Personality Compass, 7, 3, 199-216.

Gandhi, M. (1950/1957). Expériences de vérité ou autobiographie. Paris, P.U.F. English edition: An autobiography. The story of my experiments with truth. Boston: Beacon Press, 1957.

Goma, P. (1971/1977). In cerc. Paris: Gallimard.

Goma, P. (1981). Patimile după Piteşti (Les Chiens de mort ou La Pssion selon Piteşti). Paris:Hacehtte.

Goma, P. (1991). Gherla. Bucureşti: Humanitas.

Grolnick, W. S. (2003). The psychology of parental control. How wellmeant parenting backfires. Mahwah, New Jersey: Lawrence Erlbaum Associates.

Grolnick, W.S., Farkas, M. S., Sohmer, R., Michaels, S., \& Valsiner, J. (2007). Facilitating motivation in young adolescents: Effects of an after-school program. Journal of Applied Developmental Psychology 28, 332-344.

Havel, V. (1985a). The power of the powerless. Armonk, New York: M. E. Sharpe, Inc. Václav Havel, V. (1985b). Politics and conscience. In Open letters: Selected writings, selected and ed. Paul Wilson. New York: Random House, 1985).

Hanke, K., Liu, J.H., Sibley, C.G., Paez, D., Gaines Jr. S. O., Moloney, G., Leong C-H., Wagner, Licata, L., Klein, O., Garber, I., Böhm, G., Hilton, D., Valchev, V., Khan, S.S. Cabecinhas, F. (2015). "Heroes and "villains" of world history across cultures. PLOS one, February. 
Havel, V. (1986). Living in truth. Twenty-two essays published with the occasion of the award of the Erasmus Prize to Václav Havel. Edited by Jan Vladislav.. London: Faber and Faber.

Havel, V. (1988). Letters to Olga. Translated by P. Wilson. New York: Random House.

Hippel, W. von, \& Gonsalkorale, K. (2005). That is bloody revolting. Inhibitory control of thoughts better left unsaid. Psychological Science, 17, 7, 497-500.

James, M. C., \& John Johnson, J. (2000). A virtues approach to personality. Personality and individual differences, 28, 997-1013.

Janet, P. (1929). L'évolution psychologique de la perosnalité. Paris: Editions, Chahine.

Jonas, K. J. \& Brandstatter, V. (2004). Zivilcourage - Defintionen, Befunde, Massnahemn [Moral courage - definition, findings and intervention]. Zeitschrift Fur Sozialpsychologie, 35, 185-200.

Jung, C. G. (1932/1976). Symbols of transformation: An analysis of the prelude to a case of schizophrenia. In Collected works of C. G. Jung. H. Red, M. Fordham. G. Adler \& W. McGuire (Eds.), translated by R.F. C. Hull, Volume 5, Bollingen Series, Princeton N.J.: Princeton University Press.

Jung, C. G. (1936/1978). Civilization in transition. In Collected works of C. G. Jung H. Red, M. Fordham. G. Adler \& W. McGuire (Eds.), translated by R.F. C. Hull, Volume 10, Bollingen Series, Princeton N.J.: Princeton University Press.

Kuhl, J. (2008, to be published). A theory of self-development: Affective fixation and the STAR model of personality disorders and related styles. To be published in J. Heckhausen (Ed.). Motivational psychology of human development: Developing motivation and motivating development. Oxford, GB: Elsevier Science.

Kuhl, J., \& Kazen, M. (1994). Self-discrimination and memory: State orientation and false self-ascription of assigned activities. Journal of Personality and Social Psychology, 66, 1103-1115.

Lind, G. (2002). Ist Moral lehrbar? Ergebnisse der modernen moralpsychologischen Forschung. Berlin: Logos-Verlag.

Makarenko, A.S. (1963). Opere pedagogice alese (Pedgogical works), Vol. 1 \& 2. Bucureşti: Editura Didactică şi Pedagogică.

Makarenko, A.S. (1929/1973). The road to life. An epic in education. Translation with an introduction by P. Lichtenberg. New York: Oriole Editions.

Mamali, C. (1998). The Gandhian mode of becoming. Ahmedabad: Gujarat Vidyapith.

Mamali, C. (1992/2000). Oracle-Sphinx complex: Oedipus's quest for truth and love. Manuscript: University of Iowa, Project on Rhetoric of Inquiry. Iowa City - Dubuque. 
Mamali C. (2001). A Vectorial and dialectical construct of love and Sternberg's triangular model. Poster presented at the International Conference on Personal Relationships sponsored by ISSPR and INPR, June-July, Prescott-Arizona.

Mamali, C. (2003). A Vectorial construct of love and hate and Sternberg's triangular model: Toward a hexagonal model of love and hate. The International Association for Relationship Research, Bloomington/Normal, IL,USA.

Mamali, C. (2009). Manifestoes and political genealogies: Historical experiments rooted in The Manifesto of Communist Party and the Civil Disobedience. Lecture at University Johannes Kepler, Linz , June 2009, and in July 2009 in Bucharest at the Institutul de Cercetări pentru Calitatea Vieții al Academiei Române.

Mamali, C (2010). Autonomy and crucial experiences: self-regulation in autobiographical documents of Franklin, Thoreau and Gandhi. Fourth International Conference on Self-Determination Theory - Ghent, Belgium, May 13-16 2010.

Mamali, C (2011). Self-inquiry and inter-inquiry: Exploring the self's reflective potential through pictorial and self-initiated records. Sixth Self Biennial International Conference. The Centrality of SELF Theory and Research for Enabling Human Potential. Quebec City, Canada - June 19-22, 2011.

McAdams, D. P. (2006). The redemptive self. New York: Oxford University Press.

Morgan, E. (2002). Benjamin Franklin. New Haven: Yale University.

Palouš, M. (2007). Jan Patočka's Socratic message for the $21^{\text {st }}$ Century. The Conference "Jan Patočka 1907-1977”: Prague, Carolinum, 23 April 2007.

Patočka, J. (1990). La surcivilization et son conflict. In Liberté et sacrifice. Ecrits politiques. Translated by E.Abrams and J. Millon. Grenoble.

Patočka, J. (1975/1996). Heretical essays in the philosophy of history. Edited by J. Dodd, translated by Kohák. Chicago and La Salle: Open Court.

Paulhus, D. L., \& Willimas, K. M. (2002). The dark triad of personality: narcissism, machiavellianism and psychopathy. Journal of Research in Personality, 36, 6, 556-563.

Piaget, J. (1962). The moral judgment of the child. Translated by M. Gabain. New York: Collier Books.

Peterson, C., \& Seligman, M. E. P. (2004). Character strengths and virtues. A handbook and classification. Washington, DC: Oxford University Press.

Sloterdijk, P. (1987). Critique of cynical reason. Translation by M. Eldred, Foreword by Huyssen. Minneapolis: University of Minnesota Press. 
Sullivan, H. S. (1953). The theory of interpersonal psychiatry, edited by H. S. Perry \& M. L. Gawel, With and introduction by M. B. Cohen, New York, W.W. Norton.

Theophrastus (2002) Characters, Edited and Translated by J.Rusten, I.C. Cunningham.Cambridge, Harvard university Press.

Thoreau, H. D. (1981). Journal (1837-1844). Vol. 1. Edited by J. C. Broderick (General Editor), E. Hall Witherell, W. L.Howarth, R. Sattelmeyer \& T. Blanding (Editors). Princeton. Princeton University Press.

Thoreau, H. D. (1984). Journal (1842-1848). Vol 2. Edited by J. C. Broderick (General Editor), R. Sattelmeyer (Editor). Princeton. Princeton University Press.

Thoreau, H. D. (1990). Journal (1848-1851). Vol 3. Edited by J. C. Broderick (General Editor), R. Sattelmeyer, M. Patterson, W. Rossi (Editors). Princeton. Princeton University Press.

Tuan, Y.F. (1989). Morality and imagination. Paradoxes of progress. Madison: University of Wisconsin Press.

Vaillant, G. E. (1971). Theoretical hierarchy of adaptive ego mechanisms. Archives of General Psychiatry, 24, 107-118

Vaillant, G. E. (1977). Adaptation to life. Boston: Little, Brown.

Waterman, A. S. (2005). When effort is enjoyed: Two studies of intrinsic motivation for personally salient activities. Motivation and Emotion, 29, 3, 165-188.

Wundt, W. (1912). Ethik, eine Untersuchung der Tatsachen und Gesetze des sittlichen Lebens. Dritter Band: Die Prinzipien der sittlichkeit und die sittlichen lebensgebiete. Stuttgart: Verlag von Ferdinand Enke, 1912. 